\title{
Covert bacteriuria: long term follow up
}

\author{
V K Aggarwal, K Verrier Jones, A W Asscher, C Evans, L A Williams
}

\begin{abstract}
In a longitudinal prospective study 58 schoolgirls with covert bacteriuria were followed up for an average of 11.2 years (range 8.8 to 13.5 years). Intravenous urography was carried out at the start of the study (aged 4 to 11 years) and after completion of the follow up period (aged 14.8 to 22.3 years). After random allocation 27 of these girls received intermittent treatment for covert bacteriuria for the first four years and the control group received no treatment. The effect of covert bacteriuria, treatment, vesicoureteric reflux, and reflux nephropathy at presentation on the final renal length, progression of scarring, and development of new scars was analysed. No new scars were found in girls with bilaterally normal kidneys. In girls with reflux nephropathy, three kidneys showed progression of existing scars and two kidneys developed new scars. It was shown that final renal length was not influenced by vesicoureteric reflux or treatment, but reduced renal length at final assessment was associated with the presence of kidney scarring at initial assessment.
\end{abstract}

Normal kidney growth has been considered to be an index of well being of the kidney whereas poor growth has been associated with renal disease. Aperia et al have shown that kidney size is closely related to glomerular filtration rate in children with reflux nephropathy. ${ }^{1}$ It has been suggested that bacteriuria and vesicoureteric reflux inhibit renal growth as well as causing renal scarring, but there is little evidence to support this. The aim of treatment in asymptomatic individuals is to prevent renal damage. Previously studies in schoolgirls with covert bacteriuria showed that vesicoureteric reflux is present in $25 \%-33 \% .{ }^{2}{ }^{3}$ Reflux nephropathy is an important cause of severe hypertension in children ${ }^{4}$ and accounts for at least $10 \%$ of cases of end stage renal disease. ${ }^{5}$ This study has assessed the long term effect of covert bacteriuria, vesicoureteric reflux, and treatment on renal growth in asymptomatic individuals with normal kidneys and those who had evidence of reflux nephropathy at the outset of the study.

C Evans

L A Williams

Department of

Renal Medicine

A W Asscher

Correspondence to:

Dr K Verrier Jones,

Department of

Cardiff Royal Infirmary,

Newport Road,

Accepted 8 July 1991

Patients and methods

SUBJECTS AND OUTLINE OF THE STUDY

The subjects of this study were 58 females who had been identified while at primary school, aged 4 to 11 years, during a screening programme for bacteriuria. ${ }^{6}$ The outline of the study is shown in table 1. The distribution of initial radiological findings and prevalence of infection at the time of final intravenous urogram is shown in table 2 . After the initial radiological investigations girls were randomly allocated to control or treatment groups. Twenty seven girls were in the treatment group and received short courses of appropriate antibiotics according to the results of urine culture and antibiotic sensitivity of infecting organisms. After four years of follow up the controlled trial was discontinued. Subsequently long term low dose prophylaxis with trimethoprim or nitrofurantoin $1-2 \mathrm{mg} / \mathrm{kg}$ at night was offered to 12 girls who had scarred kidneys and continued infection. This was taken for less than 12 months by 10 girls and for three and four years by the remaining two girls. The two girls who took long term treatment continued to have break through infections.

\section{RADIOLOGY}

Intravenous urography was carried out at the start and after an average of 11.2 (range $8 \cdot 8-13 \cdot 5$ ) years of follow up and micturating cystourethrography at the start only, using the techniques previously described. ${ }^{3}$ All radiographs were reviewed separately by two teams of two observers for the presence or absence of scarring and on the final radiographs for the development of new or progressive scars. Each kidney was measured as well as the distance between the superior border of the first lumbar vertebra and inferior border of the third lumbar vertebra (L1-L3 height) as has been described by Eklof and Ringertz. ${ }^{7}$ Whenever there was a discrepancy in renal length or vertebral height

Table 1 Outline of the study

\begin{tabular}{lc}
\hline No of girls screened & 13369 \\
No (\%) with bacteriuria detected & 207 \\
No undergoing IVU initially & 180 \\
No completing four year follow up and IVU & 167 \\
No (\%) completing 11 year follow up and IVU & $58(32)$ \\
\hline
\end{tabular}

IVU=intravenous urography.

Table 2 Distribution of initial radiological findings in 58 girls and prevalence of infection at time final intravenous urography (IVU) performed

\begin{tabular}{lrl}
\hline Initial radiological findings & $\begin{array}{l}\text { No of } \\
\text { girls }\end{array}$ & $\begin{array}{l}\text { Prevalence of } \\
\text { infection when } \\
\text { final IVU performed } \\
(\%)\end{array}$ \\
\hline Scarred kidney(s) with reflux & 14 & 29 \\
Scarred kidneys(s) without reflux & 7 & 29 \\
Normal kidneys with reflux & 9 & 22 \\
Normal kidneys without reflux & 28 & 32 \\
\hline
\end{tabular}


of more than $5 \mathrm{~mm}$ or a discrepancy in observation of scarring the radiographs were reviewed by all four observers and agreement was reached in every case. Renal length and L1-L3 height have been taken as the mean of the two sets of observations, and kidney length expressed as a proportion of vertebral height. The grade of vesicoureteric reflux has been classified I to III as recommended by the Medical Research Council Bacteriuria Committee. The distribution of initial radiological findings in 116 kidneys (58 subjects) is shown in table 3. The effect of vesicoureteric reflux and treatment on renal length was assessed for bilaterally normal kidneys, scarred kidneys, and kidneys opposite scarred kidneys (hypertrophied kidneys). The effect of bacteriuria on renal length in girls with bilaterally normal kidneys was assessed by plotting renal length on centile charts relating renal length to the height of the individual (Hodson $e t a l^{8}$ ).

\section{STATISTICAL ANALYSIS}

The influence of vesicoureteric reflux, scarring, and treatment jointly and relatively on renal length was evaluated in a three way analysis of variance model, using the average of the lengths of the two kidneys to characterise the subject. This strategy was adopted in order to avoid the analysis being invalidated by non-independence. It was verified that the adjusted means closely correspond to what would be obtained in an analysis using the individual kidney as a unit.

\section{Results}

All of the 58 females (14 girls 14.8-17.9 years and 44 women $18 \cdot 0-22 \cdot 3$ years) were clinically well at the time of the final follow up. Although 11 women had episodes of high blood pressure recorded, none had sustained hypertension (greater than $140 / 90 \mathrm{~mm} \mathrm{Hg}$ ) or were on antihypertensive medication.

Ten women had been pregnant (12 pregnancies), seven had had one live birth each, one had had two pregnancies and two live births. There had been two terminations and one spontaneous abortion. (One woman had had a termination followed by a live birth.) Information on bacteriuria was available in the nine successful pregnancies and asymptomatic bacteriuria was documented in three. One of

Table 3 Distribution of initial radiological findings in 116 kidneys

\begin{tabular}{|c|c|c|}
\hline Initial radiological findings & & f kidneys \\
\hline Bilateral normal kidneys with reflux & 12 & $\begin{array}{ll}\text { Grade I } & 5 \\
\text { Grade II } & 3 \\
\text { Grade III } & 3\end{array}$ \\
\hline Bilateral normal kidneys without reflux & 62 & \\
\hline Scarred kidneys with reflux & 14 & $\begin{array}{ll}\text { Grade I } & 5 \\
\text { Grade II } & 3 \\
\text { Grade III } & 6\end{array}$ \\
\hline Scarred kidneys without reflux & 12 & \\
\hline $\begin{array}{l}\text { Normal kidneys } \\
\text { (opposite a scarred kidney) } \\
\text { with reflux }\end{array}$ & 6 & $\begin{array}{ll}\text { Grade I } & 0 \\
\text { Grade II } & 4 \\
\text { Grade III } & 2\end{array}$ \\
\hline $\begin{array}{l}\text { Normal kidneys } \\
\text { (opposite a scarred kidney) } \\
\text { without reflux }\end{array}$ & 10 & \\
\hline
\end{tabular}

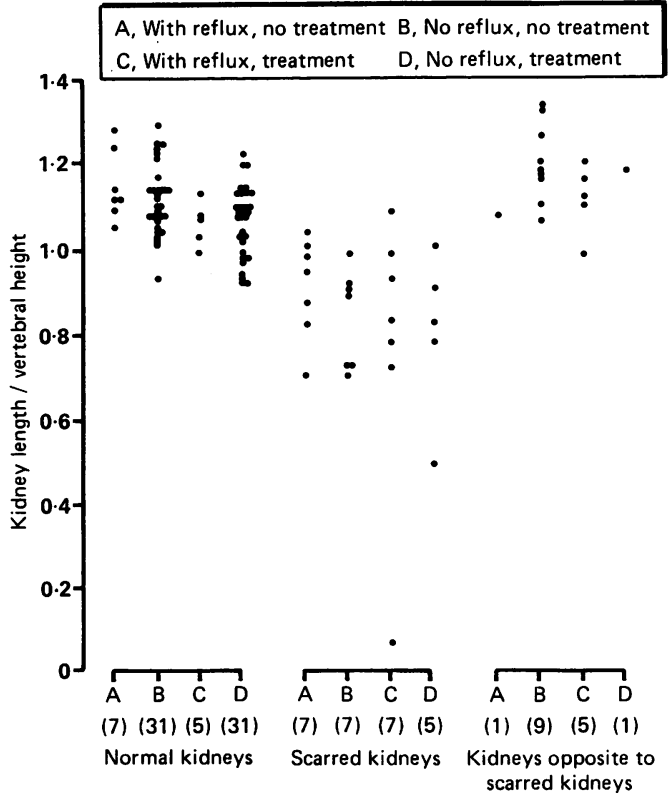

Effect of treatment and vesicoureteric reflux on final renal length in bilateral, normal kidneys and normal kidneys opposite to scarred kidneys, as assessed by ratio of kidney length/vertebral height $(\mathrm{cm} / \mathrm{cm})$. (The number of kidneys in each group are shown in parentheses.)

these women later developed symptoms of acute pyelonephritis.

No new scars developed in girls with bilaterally normal kidneys. New scars were seen in two kidneys (one normal kidney opposite to a scarred kidney and the other already scarred) both of which were drained by ureters with grade III vesicoureteric reflux. Three kidneys showed progression of scarring, all of which had refluxing ureters (grade I in one and grade III in two kidneys). One woman had a $5 \mathrm{~mm}$ renal calculus in a normal kidney and another had renal calcification in the scarred lower pole of a refluxing duplex system. Two women with scarred kidneys developed caliceal cysts. The effect of treatment and vesicoureteric reflux on final renal length is shown in the figure. There was no evidence that bacteriuria was associated with a reduction in final renal length in women with radiologically normal kidneys. Although scarred kidneys were significantly smaller than normal kidneys $(p<0.001)$, no effect of vesicoureteric reflux or treatment was demonstrated.

\section{Discussion}

The results of this study support the findings of the previous study (after four years of follow up) that new scars do not develop in girls with bilaterally normal kidneys. ${ }^{9}$ The two women who developed new scars and the three women who had progression of existing scars already had evidence of scarring and vesicoureteric reflux. While it is possible that progression of scarring in these three women might have been prevented by long term low dose prophylaxis or surgery, the benefits of these forms of intervention are not proved. The Birmingham Reflux Study Group showed that a significant number of children developed progressive scarring despite long term prophylactic antibiotic 
treatment or surgery. ${ }^{10}$ Women with covert bacteriuria, many of whom have never had clear symptoms of urinary tract infection, are poorly motivated to comply with inconvenient or painful treatment.

In addition to renal scar formation urinary tract infection may interfere with renal growth. ${ }^{11} 12$ We have shown that scarred kidneys grow significantly less well than normal kidneys $(\mathrm{p}<0.001)$ but we, like Claesson et $a l,{ }^{13}$ have been unable to demonstrate a detrimental effect of reflux or covert bacteriuria on renal growth. The final renal length of bilaterally normal kidneys with or without vesicoureteric reflux was normal even after prolonged exposure to bacteriuria.

This study has shown that the prevalence of reflux nephropathy in schoolgirls with covert bacteriuria does not change after 4 years of age. In some girls ( $24 \%$ in this study) reflux nephropathy is a slowly progressive disease. However in the absence of scarring, covert bacteriuria is benign and does not affect renal length, even if vesicoureteric reflux is present, after 4 years of age. Although further studies are required to show the best way to prevent progressive damage in girls with established scarring and persisting reflux, it is clear that the only way to reduce the prevalence of reflux nephropathy is to improve the diagnosis and treatment of infants and very young children under 4 years of age.
The authors wish to thank Miss Joanne Cook and Mrs Christa George for preparation of the manuscript and Mrs Robert Roberts for technical assistance. This study was supported by grants from the Laura Ashley Foundation, the Medical Research Council, and the Kidney Research Unit Foundation for Wales.

1 Aperia A, Broberger O, Ekengren $\mathrm{K}$, Wikstadt I. The relationship between renal area and renal function in
different well defined childhood nephropathies. Acta different well defined childhood
Radiologica: Diagnosis 1978;19:186.

2 Savage DCL, Wilson M, McHardy M, Dewar DAE, Fee WM. Covert bacteriuria of childhood. Arch Dis Child 1973;43:8-20

3 McLachlan MSF, Meller ST, Verrier Jones ER, et al. Urinary tract in schoolgirls with covert bacteriuria. Arch Dis Child 1975;50:253-8.

4 Bailey RR. Reflux nephropathy and hypertension. In: Hodson CJ, Kincaid Smith P, eds. Reflux nephropathy. New York: Masson, 1979:263-7.

5 Donckerwolcke RA, Brunner FP. Combined report on regular dialysis and transplantation of children in Europe 1981. Proceedings of the European dialysis and transplant assocation. Vol 20. London: Pitman Medical, 1982:60-91.

6 Asscher AW, McLachlan MSF, Verrier Jones ER, et al. Screening for asymptomatic urinary tract infection in schoolgirls. Lancet 1973;ii:1-10.

7 Eklof O, Ringertz H. Kidney size in children. Acta Radiologica: Diagnosis 1976;17:617-25.

8 Hodson CJ, Drewe JA, Karn MN, King A. Renal size in normal children. Arch Dis Child 1961;37:616-22.

9 The Cardiff-Oxford Bacteriuria Study Groups. Sequelae of bacteriuria-a four year follow up study in schoolgirls. Lancet 1978;i:889-93.

10 Birmingham Reflux Study Group. Prospective trial of operative versus non-operative treatment of severe vesicoureteric reflux in children: five years' observation. $B M \mathcal{F} 1987 ; 295$; $237-41$.

11 Smellie JM, Edwards D, Normand ICS. Effect of vesicoureteric reflux on renal growth in children with urinary tract infection. Arch Dis Child 1981;51:593-600.

12 Hellstrom M, Jacobsson B, Jodal U, Winberg J, Oden A. Renal growth after neonatal urinary infection. Pediatr Nephrol 1987;1:269-75.

13 Claesson I, Lindberg U. Asymptomatic bacteriuria in schoolgirls. Radiology 1977;124:179-83.
. 